\title{
De rol van bronnen in de imagologie: een case study van Vlaamse vreemdelingen, Engelse inwoners, ambtenaren en machthebbers van de stad Norwich in de zestiende eeuw
}

\begin{abstract}
In the middle of the $16^{\text {th }}$ century many people left the Low Countries for England as a result of religious persecution and economic hardship. Several thousand of these people, mainly from the Southern Netherlands, went to Norwich, the second largest city in England. Some of them wrote letters to friends and family members whom they left behind in the Low Countries, which indicate that they valued the religious freedom and economic opportunities in Norwich. This suggests that they had a positive image of the local English people. However, if one looks at official English documents, the picture is more mixed. While some English valued the economic contribution that the migrants made, others were concerned about the effect on the local workforce, and measures were taken to restrict their economic activities. Furthermore, some people in Norwich had Catholic sympathies and this was an important motivating factor in a plot to eject the migrants from the city, which ultimately failed. In short, this article uses the situation in Norwich in the late $16^{\text {th }}$ century as a case study for exploring how different sources can create contrasting images of how one group of people views another.
\end{abstract}

Keywords: imagology, migrants, Norwich, Low Countries, $16^{\text {th }}$ century.

\section{Inleiding}

De laatste tijd komt het onderwerp migratie heel regelmatig in het nieuws. Migratie is er echter altijd al geweest. In dat opzicht vormt de vroegmoderne periode daar geen uitzondering op. Naar schatting verhuisde een derde van de bevolking in die tijd in Europa binnen de eigen landsgrenzen of naar het buitenland (Schunka 2016: 78). Hoewel migranten de economie en cultuur van hun nieuwe thuis- 
land of thuisstad vaak verrijkten, waren ze niet altijd even welkom. Deze bijdrage neemt de migratie vanuit de Zuidelijke Nederlanden, en vooral Vlaanderen, naar de Engelse stad Norwich in de tweede helft van de zestiende eeuw onder de loep. Aan de hand van de beschikbare bronnen worden in dit artikel de reacties van de migranten geanalyseerd en die van de Engelse inwoners van Norwich op de komst van hun nieuwe stadgenoten en overwogen of er een verschil tussen deze reacties was en, zo ja, waarom.

Het artikel begint met een korte inleiding over het theoretische kader waarin dit verhaal wordt geplaatst, namelijk de imagologie en de rol die bronnen spelen in de vorming en bestendiging van wederzijdse imago's. Dan wordt deze migratie binnen haar historische context geplaatst. Daarna worden de bronnen beschreven die beschikbaar zijn voor deze studie; aan de ene kant privébrieven geschreven door de migranten aan vrienden en familieleden in Vlaanderen, en aan de andere kant met name officiële documenten geschreven door nationale en plaatselijke Engelse machthebbers. Vervolgens wordt ingegaan op de reacties van de migranten op hun nieuwe situatie. In dit opzicht komen religieuze vrijheid en economische welvaart vaak ter sprake. Daarna worden gelijktijdige documenten geschreven door Engelse auteurs onder de loep genomen. Uit deze bronnen blijkt dat de reactie van de Engelse machthebbers en inwoners veelzijdiger was dan wordt weergegeven in de privébrieven van de migranten. In dit artikel wordt dus op dit verschil ingegaan en een mogelijke uitleg gegeven. Aan de hand van dit verschil wordt beweerd dat de keuze en manier van behandelen van bronnen heel belangrijk zijn in het vormen van wederzijdse imago's, wat centraal staat in de imagologie.

\section{Imagologie}

Imagologie vindt haar wortels terug in de comparative literature van de naoorlogse periode (Leerssen 2016: 14). Kort gezegd gaat deze stroming uit van de beeldvorming van andere volkeren aan de hand van dominante en uitvergrote stereotypen (bijv. de Nederlander als hardnekkig en gierig) die in een veelheid aan media worden verspreid. Anders gezegd wordt in de imagologie de manier onderzocht waarop een volk of natie een imago van een ander volk opbouwt en aanhoudt en wordt verkend hoe een volk bepaalde kenmerken toeschrijft aan een ander volk (Wojtyna; Leerssen 2007: 17). In dit opzicht bespreekt Manfred Beller uitvoerig hoe de Fransen door de eeuwen heen hun imago van de Duitsers hebben opgebouwd en andersom (Beller 2007: 3-16). Op dezelfde wijze kon men het imago van Nederlanders onder de Engelsen onder de loep nemen. Zoals bekend is dit imago in een aantal opzichten negatief, vooral als gevolg van de Engelse Zeeoorlogen in de zeventiende eeuw. Wat de imagologie betreft is de 'echte' 
waarheid - zijn Nederlanders eigenlijk meer of minder zuinig of dronken dan Engelsen - minder belangrijk dan de perceptie, omdat deze laatste een bepalende rol speelt bij het ontstaan en vormen van deze imago's (Beller 2007: 4-5).

Volgens Leerssen is de hoofdtaak van imagologie het deconstrueren van nationaal en etnisch essentialisme ("the core business of imagology [is] deconstructing the discourse of national and ethnic essentialism") (Leerssen 2016: 13). In deze en de andere definities vindt men twee belangrijke elementen. Ten eerste gaan ze vooral over 'ethnotypen', die Leerssen als "stereotypical attributions of national character" (stereotypische eigenschappen van het nationaal karakter) definieert. Ten tweede tonen deze definities aan dat verschillende media, of bronnen, een centrale rol spelen in de opbouw en bestendiging van deze ethnotypen. Maar in tegenstelling tot veel van het onderzoek gedaan binnen het theoretische kader van de imagologie (bijv. Beller \& Leerssen 2007) komen in dit artikel niet zozeer ethnotypen of nationale imago's ter sprake, als imago's die hoofdzakelijk op een stedelijk of regionaal niveau zijn gevormd. Deze kunnen als 'politypen' (van het Griekse woord voor 'stad', polis) worden aangeduid. Dit artikel spitst zich namelijk vooral toe op bronnen en de manier waarop deze bronnen politypen of ethnotypen bemiddelen en in zekere mate toevoegen aan hun vorming. Van de migranten uit de Zuidelijke Nederlanden hebben we een aantal privébrieven, of egodocumenten, beschikbaar. Deze geven aan dat de migranten zonder veel moeite hun calvinistische religie konden beoefenen en hun dagelijks brood konden verdienen, en dat de Engelsen tevreden waren met hun aankomst. Als men echter gelijktijdige, vooral officiële, documenten van de Engelsen leest, komt er een complexer beeld naar voren, wat de reacties van de Engelsen op de aankomst van hun nieuwe stadgenoten betreft. Aan de ene kant waarderen sommige Engelsen de economische bijdrage die de migranten aan de stedelijke economie leverden, maar aan de andere kant waren sommigen bang dat ze een negatieve impact zouden hebben op de plaatselijke werkgelegenheid, terwijl andere Engelsen zich om religieuze redenen tegen de migranten verzetten. Met andere woorden als men slechts één bron zou lezen, zou men denken dat het imago van de migranten van de Engelsen alleen positief was. Als men echter de twee bronnen vergelijkt, dan komt men snel tot de conclusie dat dit imago niet klopt met 'de realiteit'.

\section{Historische context}

Voordat ik inga op de bronnen die in dit artikel worden gebruikt is het belangrijk om te begrijpen hoe en waarom de Nederlandse migranten in Norwich zijn terechtgekomen en daarom moet de historische context kort worden besproken. In de vroegmoderne periode was Norwich in het graafschap Norfolk in Oost-Engeland de op een na grootste stad in Engeland, na de hoofdstad Londen. 
In de late middeleeuwen werd de stad welvarend door zijn bloeiende textielindustrie. Desondanks verzwakte zijn economische situatie in het midden van de zestiende eeuw om een aantal redenen. Ten eerste was er in 1549 een opstand, Kett's Rebellion genoemd, gericht tegen de omheining van het land door rijkere landeigenaars. De opstandelingen hebben Norwich een aantal maanden bezet en veel gebouwen en huizen beschadigd of vernietigd. De wederopbouw van dit vastgoed kostte veel tijd en geld. Ten tweede was er een vermindering van de verkoop van de traditionele zwaardere wollen stoffen zoals worstead. Voor 1535 werden tussen 1,000 en 3,000 stuks worstead per jaar geëxporteerd, maar in 1561 was dit aantal een magere 38. Dit was niet alleen ten nadele van de plaatselijke werkgelegenheid en kooplui, maar bovendien kreeg de stad veel minder tolgeld. Ten derde was er een heel barre winter in 1564-1565 (Meeres 2018: 20; Moens 1887, I: 17). De plaatselijke leiders, met name de Hertog van Norfolk en burgemeester Thomas Sotherton, beseften dat de economische positie van de stad kon worden verbeterd door de uitnodiging en aanstelling van een aantal vakbekwame textielarbeiders afkomstig uit de Zuidelijke Nederlanden (Moens 1888, II: 253). Vanwege de religieuze vervolging, met name van protestanten, en uit economische nood waren er reeds duizenden textielarbeiders uit de Zuidelijke Nederlanden in Zuidoost-Engeland aangekomen, vooral in Londen en in de havenstad Sandwich in het graafschap Kent, het gebied dat geografisch het dichtst bij de Zuidelijke Nederlanden ligt. Op 5 november 1565 gaf de protestantse koningin Elizabeth I haar toestemming in de vorm van Letters Patent (open brieven) om een aantal textielarbeiders afkomstig van de Zuidelijke Nederlanden naar Norwich te laten komen (Meeres 2018: 21). Op 1 juni 1566 heeft Thomas Sotherton, in zijn hoedanigheid als burgemeester van Norwich, dertig textielarbeiders en hun familieleden uitgenodigd om zich in Norwich te vestigen (Moens 1887, I: 18-19; II: 244-245). ${ }^{1}$ De meerderheid van hen kwam uit Sandwich (Duke 2014: 117; Meeres 2018: 23, 24).

Twee maanden later, op 10 augustus 1566, brak de zogenaamde beeldenstorm uit in Steenvoorde, in de Westhoek van Vlaanderen. Zoals bekend werd dit vooral door calvinisten uitgevoerd die zich afzetten tegen de 'afgoderij' van de katholieke kerk en de heerschappij van de Spaanse koning Filips. In het kielzog van de beeldenstorm kwam er een felle reactie van de Spaanse regering tegen calvinisten en in 1567 kwam de Hertog van Alva in de Lage Landen aan, die de Raad van Beroerten instelde. Veel calvinisten moesten met name de zuidelijke delen van de Lage Landen verlaten om een mogelijke arrestatie en zelfs de doodstraf te vermijden. Velen voeren naar Engeland, de meesten naar Norfolk. Boten zoals die van Wulffaert Boeteman voeren vanuit Nieuwpoort naar de havenstad Yarmouth, waar de passagiers overstapten in kleinere boten die langs de rivier

${ }^{1}$ Norfolk Record Office, MS NCR 17d/9, transcriptie, p. 6. 
de Yare naar Norwich voeren. In het jaar 1569 bevonden zich al bijna 3000 Nederlands- en Franstalige migranten uit de Lage Landen in Norwich en twee jaar later bijna 4000 (Meeres 2018: 38, 39). Destijds maakten zij meer dan een derde uit van de bevolking van Norwich. Terwijl sommige inwoners deze stand van zaken waardeerden, met name voor de economie van de stad, waren anderen minder tevreden met de nieuwe omstandigheden. Hier komen we straks op terug.

\section{Bronnen}

In dergelijke situaties kan het moeilijk zijn enig inzicht te krijgen in de meningen en reacties van migranten op hun nieuwe thuisland of -stad. In dit geval hebben we echter een aantal brieven die migranten in het Nederlands (of beter gezegd het West-Vlaams) hebben gestuurd naar hun vrienden en familieleden die in de Zuidelijke Nederlanden waren achtergebleven. Veel nieuwelingen waren afkomstig uit Ieper en de daaromheen liggende dorpen in de Westhoek van Vlaanderen, zoals Belle en Kassel. Waarom zoveel Ieperlingen naar Norwich kwamen is niet bekend, maar heeft wellicht te maken met het feit dat een van de hervormde predikanten in Norwich, Karel Ryckaert, van Ieper afkomstig was (Duke 2014: 117). Brieven die zij tussen 1567 en 1569 vanuit Norwich naar Ieper stuurden werden onderschept door de Spaanse autoriteiten en bewaard in een archief dat in de loop der tijd deel uitmaakte van het Ieperse stadsarchief. Helaas zijn deze brieven tijdens de Eerste Wereldoorlog vernietigd, maar gelukkig waren ze in het midden van de negentiende eeuw deels overgeschreven door de Nederlandse protestantse dominee en kerkhistoricus, Hendrick Janssen. De gedeeltelijke transcripties van de ongeveer dertig brieven vormen de belangrijkste bron voor de reacties van de migranten op hun nieuwe omstandigheden. Helaas ontbreken dergelijke brieven van de Engelse inwoners van Norwich, maar er zijn wel andere bronnen beschikbaar, waaronder de stadsdocumenten, klachten tegen de migranten die werden ingediend bij de Privy Council (d.w.z. de Raad van Bestuur van de koningin), verslagen en zelfs een gedicht over een poging om de migranten uit de stad te verdrijven. Daarmee krijgen we wat inzicht in de situatie van beide kanten.

\section{De brieven naar Ieper}

Van de brieven die de migranten naar vrienden en familieleden in Ieper stuurden kon men snel tot de conclusie komen dat zij heel positief waren over hun nieuwe thuisstad en stadgenoten, vooral wat hun religieuze vrijheid en economische welvaart betreft. Zoals reeds vermeld kwamen de meeste, zo niet alle migranten, naar Norwich omdat ze calvinisten waren. In 1565 werd er een Nederlandse (of 
Vlaamse) kerkelijke gemeente in Norwich gesticht. Voor hun kerkdiensten huurden de migranten het voormalige Dominicaanse klooster af, dat na de Reformatie eigendom was geworden van de stedelijke corporatie. Hiermee verwierf de stad een vrij groot inkomen, zo ook van de huuropbrengst van de kerk van de H. Maria (St. Mary the Less), die de migranten afhuurden om als lakenhal te gebruiken. Uit de brieven blijkt dat de nieuwelingen het op prijs stelden hun religie in vrijheid en in het openbaar te kunnen beoefenen. De dochter van Pieter de Wert, Maeyken, schreef aan haar ouders dat er vrije godsdienst was (Janssen 1857: 246). Een andere nieuwe inwoner, Claes van den Nieuwenhuuze, schreef in zijn brief aan Joes van Lomme dat hij het op prijs stelde dat het Woord Gods zo rijkelijk kon worden gepreekt in Norwich en in het naschrift schreef hij dat de zoon van Clement Kuen "horde predyken Pieter Haezaert ende Tyofylus (d.w.z. Theofilus of Karel Ryckewaert) nae den zondach dat hy wech torck (trok), daerof dat hy den Heere danct van zijn ghenaede" (Janssen 1857: 245). Jacob Muus schreef aan zijn vrouw dat als ze naar Engeland zou komen "ghy hier Godes woort hooren zult predicken" (Janssen 1857: 224). Clement Baet vertelt zijn vrouw over Norwich dat "het esser lievelic, vredelick om 'twoort te hooren" (Janssen 1857: 231). Op dezelfde wijze moedigt de man van Paescinken Kuveliers (zijn naam is onbekend) haar aan om naar Engeland te komen, waar "wy goddelic zouden leven". Jan Willemsz schrijft aan zijn zus Lysbeth, dat hoewel er een geschil tussen dominees in de kerkgemeente was geweest "al [nu] wel gaet tot Norwits (d.w.z. Norwich)" (Janssen 1857: 249, 270). In 1569 schreef Gilles Navegeer aan zijn grootmoeder dat hij en zijn familieleden in Norwich "in groete gerusticheyt ende stillecheyt" woonden en dat "het woordt Gods zeer rijckelic met ons" was (Janssen 1857: 273). Ook andere schrijvers vermelden de religieuze vrijheid die ze in Norwich ervoeren en er is geen sprake van tegenstand tegen het oefenen van hun calvinistische geloof.

Voordat ik inga op wat de auteurs van deze brieven schreven over hun economische situatie in Norwich zijn ook twee andere brieven van groot belang, wat religieuze vrijheid betreft. We kunnen ervan uitgaan dat de auteurs van deze brieven zich ervan bewust waren dat de brieven konden worden onderschept door de vijand, d.w.z. door de Spaanse autoriteiten. Daarom gebruikten sommige auteurs een pseudoniem voor zowel zichzelf als voor de geadresseerde(n). De auteur van twee brieven die in november 1567 werden geschreven, noemde zich "Typer" d.w.z. Te Yperen (Ieper). Hoewel hij nu veilig in Norwich zat, kan men vermoeden dat deze Typer bekend was bij de Spaanse autoriteiten, misschien wel een van de leiders van de beeldenstorm, en dat hij vreesde dat ze wraak zouden nemen op familieleden die in de Westhoek waren achterbleven, maar op dit moment kon men niets concreters zeggen. De geadresseerde was in beide gevallen "Lazarus", een Bijbelse naam die nogal eens als pseudoniem diende (Janssen 1857: 240). In 
zijn tweede brief, geschreven op 6 november 1567, beschrijft Typer het huis in Norwich waar hij woont:

\begin{abstract}
Wy wonen hier inde Hoochstrate int huus van meester Thomaes, eē zeer schone prinselicke plaetse. Ic ben hier int schoonste vanden huze stille alleene, met eē schone camer al ghestoffeert ende twee kamerkins aen sijde ter vertreck aen ons camer, ende eē schoon plaeysant hof voor my, eē schone kelder: ic en soude in Yper gheen schoonder woenste vinden; met eē plaese int middel, eē boghaert, ghemeene weye, hove [...]. (Janssen 1857: 240).
\end{abstract}

Hier komen we bij de vraag of dit huis nog bestaat en, zo ja, waar? De sleutel hier is "meester Thomaes". Het is hoogstwaarschijnlijk zo dat dit verwijst naar Thomas Sotherton, de bovengenoemde burgemeester van Norwich die ook parlementslid voor deze stad was geweest. Eigenlijk was hij de eigenaar van een groot huis dat nu Strangers' Hall heet en een museum huisvest over de migranten die men Strangers (d.z.w. vreemdelingen) noemde. Dat huis, dat al sinds de veertiende eeuw bestaat, staat op de huidige Charing Cross, een straat die volgens oudere kaarten van de stad destijds High Street (Hoochstraat dus) heette. Van deze twee brieven kan men dus afleiden dat de religieuze omstandigheden in de Zuidelijke Nederlanden heel gevaarlijk waren voor sommige migranten, en daarom waarderen ze de kans om in Engeland hun religie relatief vrij te kunnen beoefenen. Bovendien was er een economisch voordeel voor Engelse machthebbers zoals Sotherton die kamers of huizen aan de migranten verhuurden.

Wat schreven de auteurs van deze brieven over hun economische omstandigheden? Andries en Anna van der Haghe vertellen hun ouders dat als ze naar Norwich zouden komen ze genoeg geld zouden kunnen verdienen; "Wilt oock niet besoorcht zijn om uwen cost te winnen" (Janssen 1857: 229). In zijn brief aan Victor de Vinck geeft Leonard Keerlinck aan dat het in Norwich goedkoper was dan in Ieper; "men (coopt) hier meer om een stuiver dan, soo ick hoore, t' Yper om drie" (Janssen 1857: 230). In zijn brief aan Carolus van Houcke, schout van Ieper, maakt Jan de Haze eveneens een vergelijking tussen de omstandigheden in de Zuidelijke Nederlanden en die in Norwich en vond die in hun nieuwe thuisstad gunstiger: "zy deden ons [te Nieuwpoort] zonder bedde slapen ende mijn zes kinderen oock [...] daer we zijn [te Norwich] hebben we goeden tit ende win[st] van alles" (Janssen 1857: 244). Zoals hierboven genoemd was Nieuwpoort de vertrekhaven van de boot van Wulffaert Boeteman. Het is goed mogelijk dat Carolus en zijn familieleden in de boot van Wulffaert met andere vluchtelingen naar Engeland zijn gevaren.

Sommige migranten konden hun oude ambacht blijven uitoefenen, bijv. de wevers van nieuwe, vaak lichtere, soorten wollen weefsels, zoals saaien en baaien, "de nieuwe draperij" genoemd, of andere textielarbeiders, zoals ververs en wolkammers. Blijkbaar konden andere migranten ook geld verdienen als baaiwerkers. De dochter van Pieter de Wert bijvoorbeeld schreef aan haar ouders dat zij 
en haar nicht "leeren baai spinnen" (Janssen 1857: 246). Clement Baet vertelt zijn vrouw dat ze hun dagelijks brood kunnen verdienen "in de baey, ende ic zal zien om een huus (huis) [...] om ons in die neringe te behelpen; want daermede den cost te wel te winnen es" (Janssen 1857: 231). Anderen moesten eveneens een nieuw vak leren. Hans Losynghier schreef aan Gabriel van Dale dat hij zijn oude ambacht in Norwich niet kon uitoefenen en daarom leerde hij om saai, een van de lichtere soorten wollen weefsels, te kammen (Janssen 1857: 251). In 1569 schreef Gilles Navegeer aan zijn grootmoeder dat hij in de leer was voor boekbinder, maar omdat hij daarmee te weinig geld verdiende, moest hij dat opgeven en een ander vak leren. Hij vermeldde eveneens dat Pieter Bake van Ieper een brouwerij in Norwich was begonnen, dat zijn broer Willekin bezig was een nieuw ambacht als messenmaker te leren en dat zijn vader en zijn zus Maeyken garen sponnen om hun dagelijks brood te verdienen (Janssen 1857: 273-274).

In zijn brief aan zijn broer Mahieu vermeldt Gilles de Vinck de Hertog van Norfolk die, zoals reeds vermeld, een belangrijke rol had gespeeld in het uitnodigen van de migranten. Gilles vertelt zijn broer dat hij dagelijks "int hoof van den duuck van Nortfoock (d.w.z. de hertog van Norfolk)" is "den welcken es eenen naest de coneginne" (d.w.z. die een van de vertrouwelingen van de koningin was). "'t hoof" (hof) of paleis van de hertog stond aan de rivier de Wensum, minder dan 100 meter van het net besproken huis van Thomas Sotherton, dat nu Strangers' Hall heet. Helaas weten we echter niet wat Gilles elke dag in het paleis van de hertog deed (Janssen 1857: 233).

Wat het imago van de migranten van hun Engelse stadgenoten aangaat, geeft Clais van Wervekin ons het beste inzicht in een brief aan zijn vrouw, waarin hij haar aanmoedigt om naar Engeland te komen; "ghy ne soudt nemmermeer ghelooven, hoe vriendelick dat tvolk tsaeme es, ende oock de Ynghelschen, hoe minsaemich zy tot onser natie vallen". Vervolgens schrijft hij "dat ghy hier waert met half ons goedt, ghy ne soudt nemmermeer peinsen om in Vlaenderen te comen woonen". Hoewel alles voor Clais heel goed ging in Engeland, miste hij wel een aantal voor hem belangrijke producten. Hij vraagt zijn vrouw om "een troch" (een trog of kneedbak) mee te brengen "want men hier gheene en vint; zy cneeden al[le]s in teelen, twelke zeere zassaem (onhandig) es". Bovendien "wilt ooc coopen twee houten schotelkins om bueter half ponden in te maeken [...] want ze hier al verchs (varkensvet) [is]" (Janssen 1857: 226; Duke 2014: 127).

Van deze brieven lijkt dat voor de auteurs Norwich een stad was waar zij hun calvinistische of hervormde religie vrij konden beoefenen en de kans hadden om een baan te vinden en genoeg geld te verdienen, kortom dat hun imago van hun nieuwe thuisstad en stadgenoten vrij positief was. Men moet zich echter afvragen of dit imago de realiteit weerspiegelde en, zo niet, waarom niet. Het kan bijvoorbeeld zo zijn dat Gilles de Vink indruk wilde maken op zijn broer en andere familieleden als hij schrijft dat hij wordt aangesteld door de Hertog van Norfolk 
"den welcken es eenen naest de coneginne". Het kan ook zo zijn dat de auteurs in zekere mate overdreven om hun vrienden en familieleden ervan te overtuigen dat ze hun thuisland zouden moeten verlaten. In dit opzicht maakten ze vaak een vergelijking tussen de stand van zaken in Norwich en die in Vlaanderen wat religieuze vrijheid en de kosten van levensonderhoud betrof. Bovendien waren ze wellicht bang dat met hulp van tolken de Engelse machthebbers hun brieven zouden kunnen onderschepen, vertalen en lezen en om die reden wilden ze alleen maar positieve dingen over hun nieuwe thuisstad schrijven. Hoe dan ook is het duidelijk dat de auteurs de indruk wilden geven dat ze de religieuze vrijheid en economische welvaart in Norwich op prijs stelden. Als we echter naar Engelse documenten kijken, zien we dat de situatie in beide opzichten complexer was dan wat men van de brieven van de migranten zou kunnen afleiden.

\section{De reactie van de Engelse inwoners op de komst van de migranten uit de Zuidelijke Nederlanden}

Wat de economische omstandigheden van de migranten betreft, geven de Engelse documenten een vrij complex beeld. Aan de ene kant is er sprake van de bijdrage die de migranten hebben geleverd aan de economie van Norwich, die in zekere mate ook te zien is in de brieven van de migranten, maar aan de andere kant ziet men dat wat spanningen waren ontstaan als gevolg van de toestroom van de migranten.

Ten eerste moet worden gesteld dat de teksten waarop we ons hier baseren van een heel andere aard zijn dan de brieven die we net hebben besproken. Dit waren vooral officiële documenten waarvan de auteurs meestal ambtenaren en hooggeplaatste Engelsen waren. De eerste dertig vakbekwame textielarbeiders werden uitgenodigd naar Norwich te komen om de economische positie van de stad na de barre winter van 1564/1565 te versterken. Niet al de machthebbers in Norwich waren tevreden met deze uitnodiging. De burgemeester moest namelijk zijn eigen zegel op de uitnodiging plaatsen, omdat de gemeenteraad dat had geweigerd (Meeres 2018: 22). Tien jaar later, in 1575, werd een officieel document opgesteld waarin het effect van de migranten op de stad Norwich werd beschreven. Dit document, dat in het Nationaal Archief in Londen wordt bewaard, schildert vooral de economische bijdrage van de nieuwkomers af. De titel van het document zegt het al: "The benefittes (voordelen) received in Norwich by havying the strangers (vreemdelingen) there" (Moens 1888, II: 262-263; State Papers Domestic, Elizabeth, XX, 49). Aan het einde van het document wordt geschreven dat de migranten "do diligently and loborously attende upon their severall occupations" (d.w.z. zich bekwaam en ijverig bezig houden met een aantal vakken). Wat ook toevoegt aan het positieve beeld van de migranten, is 
het feit dat de auteurs van het document vermelden dat de migranten niet alleen andere vreemdelingen aannamen, maar ook een aantal Engelse inwoners uit de stad en omgeving, waaronder een aantal armere mensen ("of the porer sorte"). Bovendien betaalden de migranten lokale belastingen en ook o.a. het salaris van hun dominees ("they be contributors to all payments as subcedies, taskes, watches, contrubusions, mynisters, wagis \&c."). Het spreekt vanzelf dat de overheid dit op prijs stelde.

Acht jaar na het schrijven van dit document brachten de politieke leiders van Norwich de economische voordelen van de migranten nog eens ter sprake. In 1583 schreven de burgemeester en parlementslid Robert Sucklinge en de schepenen van Norwich naar de Privy Council (de raad van de koningin) om deze voordelen vast te leggen. De aanleiding hiervoor was een klacht van Nicholas Wryght ("an English informore") tegen vier migranten. Hij beweerde o.a. dat ze meer dienstknechten en -meisjes in dienst hadden dan hun was toegestaan. Sucklinge heeft de klacht echter afgewezen en de Privy Council eraan herinnerd dat de vreemdelingen de stad veel economische voordelen ("no small benefit") hadden gebracht én, wat echt bepalend was, dat ze naar Norwich waren gekomen met toestemming van de koningin zelf (Moens 1888, II: 263). In dit voorbeeld ziet men echter dat niet iedereen tevreden was met de aankomst van de migranten.

Een andere stadsleider die niet tevreden was met de nieuwe omstandigheden was de schepen Thomas Whalle. In 1570 schreef Whalle aan Clement Paston, lid van een van de voornaamste en rijkste families in Norfolk, dat de migranten "did but sucke the lyvenges away from the Inglishe". Drie jaar daarvoor, in 1567, verklaarde Whalle die destijds burgemeester van Norwich was, dat hij de komst van de migranten niet prettig vond ("[he] had no liking for the Strangers"), en hij beweerde dat ze uit de stad moesten worden geworpen ("avoide"), maar de andere schepenen hebben dit voorkomen. Niettemin heeft Whalle erop aangedrongen dat de vreemdelingen elk jaar een aantal mannen ("politicke mannen" genoemd) zouden moeten kiezen om de orde onder hen te handhaven. Bovendien eiste Whalle dat de burgemeester de gekozen mannen zou moeten goedkeuren. Whalle lijkt een complexe man te zijn en er zaten misschien ook religieuze redenen achter zijn uitingen. We komen straks op hem terug.

Blijkbaar veranderde de situatie wat de nieuwkomers betreft niet onmiddellijk. In 1568 moest Thomas Parker, Whalles opvolger als burgemeester, een uitgaansverbod na 8 uur 's avonds invoeren, omdat de inwoners klaagden dat de migranten onrust veroorzaakten: "the moste dysordered persons walked late in the streets of the citye drunken and of greate disorder". Daarnaast waren sommige Engelse inwoners bang dat de migranten hun werk zouden afnemen. Daarom waren de economische activiteiten van de nieuwkomers in zekere mate beperkt. Vanaf 1568 mochten de migranten bijvoorbeeld voor de middag geen wol op de markt kopen (Moens 1887, I: 20). In hetzelfde jaar besloot de Mayor's Court (een 
gerechtshof waarvan de burgemeester de Rechter was) dat de nieuwkomers geen schapen-, lams- of kalfshuiden van de slagers mochten kopen, omdat de Engelse handschoenmakers en leerwerkers klaagden dat ze er geen konden aanschaffen voor hun neringen (Meeres 2018: 25-27).

Naar aanleiding van een mislukte samenzwering van 1570 om de vreemdelingen uit de stad te werpen, werden de leiders van de stadsoverheid zich ervan bewust dat de komst van de vreemdelingen spanningen onder de Engelse inwoners had veroorzaakt. Daarom werd besloten om hun activiteiten strenger te controleren en vervolgens werd een Boek van Reglementen (in het Engels: Book of Orders) voor de vreemdelingen geschreven. Daarin werd o.a. voorgeschreven wat de vreemdelingen mochten kopen en verkopen, waar en wanneer ze dat mochten doen en wat voor boete ze zouden krijgen als ze zich niet aan deze reglementen hielden (Joby 2015: 134, 135; Rickwood 1989). In dit opzicht vonden de auteurs van het document van 1575 het belangrijk om te vermelden dat de migranten zich wel aan de reglementen hielden "[they] obey all magistrates and all good lawes and ordynaunces, they lyve peaceablie amonge themselves and towarde all men, and we thinke our cittie happie to enjoye them".

Kortom waren er zowel positieve als negatieve reacties onder de Engelsen wat de economische bijdrage van de migranten aan de stad aangaat. Wat religie betreft schreven de auteurs van het document van 1575 dat "They (d.w.z. de migranten) for the moste parte feare God". Bovendien stelden sommige geloofsgenoten in Norwich prijs op hun komst. In dit opzicht beweert Matthew Reynolds dat Thomas Sotherton, samen met anderen zoals zijn zwager de schepen John Aldrich, de migranten niet alleen verwelkomden vanwege de economische bijdrage die ze konden leveren aan de stad, maar ook omdat ze protestanten waren (Reynolds 2005: 52). Sommige leiders van de vrij recent opgerichte anglicaanse kerk waren bang dat er onder de migranten 'ketters' waren zoals anabaptisten. Daarom heeft de bisschop van Norwich, John Parkhurst, op aanvraag van de aartsbisschop van Canterbury, Matthew Parker, in 1568 een telling uitgevoerd om te controleren welke migranten lid waren van de Nederlandse hervormde kerk.

Er waren echter zorgen over het geloof van de migranten, niet alleen van de kant van de nationale en plaatselijke religieuze leiders. Ook de bovengemelde Thomas Whalle had bezwaren tegen de migranten op basis van hun geloof. Maar volgens Matthew Reynolds komt dit van het feit dat hij eigenlijk crypto-katholiek was, wat pas recentelijk wordt bekend (Reynolds 2005: 52). Het voorbeeld bij uitstek van de religieuze tegenstand tegen de migranten is de bovengemelde samenzwering van 1570 om de vreemdelingen uit de stad te werpen. Volgens Reynolds was de leider van de samenzwering John Throgmorton, "a known Catholic resident in the city" (Reynolds 2005: 55). Een andere leidende samenzweerder, George Redman, had volgens Reynolds contacten met bekende katholieken zoals de voormalige kloosterbroeder, Edmund Harcocke. Een derde leider, Christopher 
Plater, was de zwager van Throgmorton en ook bekend als een absoluut katholiek. De samenzwering werd tijdig ontdekt en Throgmorton, Redman en een andere samenzweerder, Thomas Brooke, werden gearresteerd en tot de doodstraf veroordeeld (Moens 1887, I: 27). Vlak voordat hij werd geëxecuteerd, schreef Brooke een gedicht waarin hij zijn spijt betuigde. Vrij ironisch is het feit dat Brookes gedicht werd uitgegeven door de vreemdeling Anthonie de Solempne uit Brabant, die tussen 1567 en 1570 boeken en pamfletten voor met name de Nederlandse kerk in Norwich drukte (Sessions \& Stoker 1987: 36).

Tegen het einde van de zestiende eeuw keerde een aantal van de migranten terug naar de Lage Landen, vooral naar Leiden en soortgelijke steden in de noordelijke Verenigde Provincies, waar ze hun calvinistische godsdienst konden uitoefenen. Degenen die in Norwich bleven wonen, assimileerden geleidelijk aan met de plaatselijke bevolking. Hoewel er af en toe enige spanningen waren, namen deze af en werd er geen nieuwe poging gedaan om de nieuwkomers uit de stad te verdrijven.

\section{Conclusies}

In dit artikel is een poging gewaagd om aan te tonen hoe verschillende bronnen uiteenlopende imago's kunnen geven van hoe een groep mensen tegen een andere groep mensen aankijkt. De aanleiding voor het ontstaan van deze bronnen was de komst van duizenden migranten vanuit de Zuidelijke Nederlanden naar de Engelse stad Norwich in de tweede helft van de zestiende eeuw. Uit brieven die deze migranten schreven aan vrienden en familieleden die in de Westhoek waren achtergebleven, kon men concluderen dat ze hun calvinistische religie zonder veel moeite konden beoefenen en dat ze hun dagelijks brood konden verdienen zonder enige beperkingen - met andere woorden kon men concluderen dat de Engelsen tevreden waren met de aankomst van hun nieuwe stadgenoten. Als men naar de Engelse bronnen kijkt, komt men echter heel snel tot de conclusie dat de reacties van de Engelse op de aankomst van de migranten veel complexer waren dan men kon afleiden van de brieven van de migranten.

Wat de economische bijdrage van de migranten aan hun nieuwe thuisstad betreft, waren sommigen, zoals de auteurs van het document van 1575, er tevreden mee. Andere leiders waren echter minder tevreden en ze wilden de economische activiteiten van de nieuwkomers in zekere mate beperken. Wat religie betreft waren sommige Engelse leiders bang dat zich ketters onder de migranten bevonden. Aan de andere kant waren er katholieken in de stad die tegen de komst van de protestantse migranten waren en in 1570 probeerden die om de nieuwkomers uit de stad te werpen. Het feit dat zulke pogingen mislukten en dat de leiders van de samenzwering van 1570 tot de doodstraf werden veroordeeld, heeft deels 
te maken met het feit dat de migranten door de koningin zelf waren uitgenodigd naar Norwich te komen. Dit toont echter aan, dat niet iedereen tevreden was met de aankomst van de migranten.

Zoals bovengemeld (deel 2) schreef Joep Leerssen (2016: 13) in 2016 dat "the core business of imagology: [is] deconstructing the discourse of national and ethnic essentialism". Dit artikel ging niet zozeer over 'the discourse of national and ethnic essentialism' als over hoe een groep of volk in een stad een andere groep of volk beschouwt, m.a.w. liever over politypes dan ethnotypes. Bovendien schrijft Leerssen (2016: 25) dat het beeld van anderen dat men krijgt afhankelijk is van de bronnen. Daarom moeten wetenschappers die zich met de imagologie bezig houden aandacht besteden aan de bronnen waaruit deze ethnotypes of politypes ontstaan. In dit opzicht toont dit artikel aan dat twee verschillende bronnen geschreven door twee verschillende bevolkingsgroepen heel uiteenlopende beelden kunnen geven van de stand van zaken tussen deze twee groepen. Daarom is het heel belangrijk om een scala aan bronnen te kiezen, hier zorgvuldig mee om te gaan en de motivaties van de auteurs goed te verkennen om te proberen zover mogelijk te begrijpen waarom ze schrijven wat ze schrijven over een andere bevolkingsgroep.

\section{Bibliografie}

Beller, Manfred (2007): “Perception, image, imagology”. In: Manfred Beller \& Joep Leerssen (red.), Imagology: The Cultural Construction and Literary Representation of National Characters: A Critical Survey. Amsterdam: Rodopi, 3-16.

Beller, Manfred, \& Joep Leerssen (red.) (2007): Imagology: The Cultural Construction and Literary Representation of National Characters: A Critical Survey. Amsterdam: Rodopi.

Duke, Alastair (2014): "Eavesdropping on the correspondence between the strangers, chiefly in Norwich, and their families in the Low Countries 1567-70". Dutch Crossing 38:2, 116-131.

Janssen, Hendrick Q. (1857): "De Hervormde Vlugtelingen van Yperen in Engeland". Bijdragen tot de Oudheidkunde en Geschiedenis inzonderheid van Zeeuwsch-Vlaanderen, Deel 2, 211-304.

Joby, Christopher (2015): The Dutch Language in Britain (1550-1702). Leiden: Brill.

Leerssen, Joep (1998): "Irish studies and Orientalism: Ireland and the Orient". In: C.C. Barfoot \& Theo D'haen (red.), Oriental Prospects: Western Literature and the Lure of the East. Amsterdam: Rodopi, 161-165.

Leerssen, Joep (2007): “Imagology: History and method”. In: Manfred Beller \& Joep Leerssen (red.), Imagology: The Cultural Construction and Literary Representation of National Characters: A Critical Survey. Amsterdam: Rodopi, 17-32.

Leerssen, Joep (2016): "Imagology: On using ethnicity to make sense of the world". Iberic@l, Revue d'études ibériques et ibéro-américaines 10, 13-31.

Meeres, Frank (2018): The Welcome Stranger: Dutch, Walloon and Huguenot incomers to Norwich 1550-1750. Norwich: Lasse Press.

Moens, William J.C. (1887-1888): The Walloons and Their Church at Norwich: Their History and Registers 1565-1832. 2 delen. Lymington: The Huguenot Society. 
Reynolds, Matthew (2005): Godly Reformers and Their Opponents in Early Modern England: Religion in Norwich c. 1560-1643. Woodbridge: Boydell.

Rickwood, Douglas L. (1989): The Norwich Dutch and Walloon Strangers'Book of Orders. 2 delen. University of East Anglia: M. Phil. Dissertation.

Schunka, Alexander (2016): “"No return?' 'Temporary exile to permanent Immigration among confessional migrants in the early modern era". In: Jason Coy e.a. (red.), Migrations in the German Lands, 1500-2000, Oxford: Berghahn, 67-88.

Sessions, William K., \& David Stoker (1987): The First Printers in Norwich from 1567 - Anthony de Solempne, Albert Christiaensz and Joannes Paetz. Norwich: W.K. Sessions.

Wojtyna, Miłosz (2018): "Narratology and imagology". Tekstualia 1:4, 125-144. 